\title{
Performance Improvement of Fruit Ripeness Smart Label Based On Ammonium Molibdat Color Indicators
}

\author{
Ade Iskandar", Indah Yuliasih", Endang Warsiki ${ }^{\#(*)}$ \\ \#Department of Agroindustrial Technology, Faculty of Agricultural Technology and Engineering, Bogor Agricultural \\ University. $2^{\text {nd }}$ Floor FATETA Buding, IPB Dramaga Campus Bogor, Indonesia 16680 \\ *Corresponding author: endangwarsiki@apps.ipb.ac.id
}

\begin{abstract}
Research in fruit ripeness indicator is still experiencing especially due to major difficulties of several fruits with no color changes in its skin when it is ripen. From the previous research, there was found that ammonium molybdate $\left[\left(\mathrm{NH}_{4}\right) 6 \mathrm{Mo}_{7} \mathrm{O}_{24} \cdot 4 \mathrm{H}_{2} \mathrm{O}\right]$ embedded in the polymer matrix could be used as an indicator label to detect the ripeness of climacteric fruits base on the color change from yellow to blue and then green. However, the performance label still needs to be developed further. The surface of the label was still poor due to air or bubble trapping inside the film. It was found that mixing $\mathrm{H}_{2} \mathrm{O}_{2}$ and molydate agent produced air or bubble thus in this research, a pre-treatment of film solution was done to chase away the air by storing and vacuuming the solution in cold temperature and time period of storage. A variety of film drying method was also carried out to find the best temperature of the oven to produce smooth surface of the film. The sensitivity of the label to ethylene gas was improved by adding more agent solution into the film. The best form of smart labels was produced using an oven at $40^{\circ} \mathrm{C}$ for 18 hours. The label composition was $100 \mathrm{~mL}$ distilled water, $3.5 \mathrm{~g} \mathrm{PVOH}, 2 \mathrm{~mL}$ glycerol, and a color indicator solution (ammonium molybdate and hydrogen peroxide ratio of 1:10) at $4 \mathrm{~mL}$. The molydate solution had to be stored for 3 days in temperature of $7^{\circ} \mathrm{C}$ before used. The label sensitivity was improved as low as 100 ppm of pure ethylene gas. Label application in a pack of avocados showed a relationship between label color changes and fruit quality degradation. The value of hue label on days 0 to 6 changed from yellow to greenish yellow, while on the $7^{\text {th }}$ to the $10^{\text {th }}$ day the color of the label was still in the same color as the day of $6^{\text {th }}$. Decreasing the quality of fruit during storage can be seen from the increase in the percentage of weight loss and hardness of fruit texture.
\end{abstract}

Keywords - Smart label; ripeness indicator; ammonium molibdate; avocado

\section{INTRODUCTION}

Fruit is continuing life even after harvest by means the respiration of fruits keeps on going until all supplies have been depleted. Fruit respiration produces ethylene, carbon dioxide and moisture. Ethylene is plant gas hormone which plays a key regulatory role in ripening process. This gas also represents important changing in physical and chemical properties of fruit such as the content of vitamins, minerals, acids, sugar and texture [1]. According to [2] to determine ripening of fruit, practically in the market, was done by checking skin color, hardness or softness, size, and shape of the fruit. However, not all types of fruit expose their maturity through visual appearance such as skin discoloration. Some fruits do not experience skin color changing at its maturities such as avocados, some mangoes, pears, dragon fruit, and ambonese bananas. Thus, pressing or bruising the fruit to ensure the level of fruit maturity is wrong practice. Bruising or pressing the fruit, further, can increase respiration patterns and produce ethylene higher thus the fruit decomposes faster [3].

According to [4], fruit maturity can also be detected based on the skin image color features using the HIS (Hue, Intensity, Saturation) color space transformation method. Color space system transformation method is one method of image processing in order to obtain color space from an image in a particular color coordinate system. But the application of this method is only limited to the laboratory because it takes time and involves difficult calculations to determine the color of fruit maturity. A penetrometer can also be used to determine the level of fruit maturity by measuring the level of hardness or softness of fruit texture [5]. According to [6], a decrease in the level of fruit texture will accelerate the decay and increase the 
potential for fruit damage during handling. The penetrometer work by pressing or piercing the fruit with a stainless steel needle at a certain depth for 5 $\mathrm{mm}$ in a second, the smaller the hardness value means the fruit is soft and once the fruit is ripe. However, this method is considered less effective because it will leave fruit stab wounds thus it trigger fruit rotten. Therefore, a simple maturity detector is needed to accommodate consumers to choose fruit according to their needs. One innovation is the inclusion of smart labels embedded in a package of fruit known as smart indicator label [2] or smart packaging.

Smart packaging is a package that has an ability to monitor and provide information regarding the condition of packaged foods that change due to the influence of temperature [7], $\mathrm{pH}$ [8] and microbial growth [9]. Unlike conventional packaging which only provides fixed product information, smart packaging is dynamic so that it is able to know the changes in product quality in timely. Indicator label to detect fruit maturity has been done [2]. The result so far was still poor; the label broke when it absorbs moisture produced by the fruit during the respiration process. Whereas in the other research [10], the label contained air trapped inside the film, thus visually the label is less attractive. Therefore, this study was conducted to improve the visual label appearance and also and increase label sensitivity of the label to ethylene gas. This label was expected to detect the maturity of the climatic fruit practically by being a change in the color of the label from yellow to green in accordance with increasing ethylene gas produced by the fruit.

\section{MATERIALS AND METHODS}

\section{A. Materials and equipment}

Materials used included ammonium molybdate $\left[\left(\mathrm{NH}_{4}\right)_{6} \mathrm{Mo}_{7} \mathrm{O}_{24 \cdot 4} \mathrm{H}_{2} \mathrm{O}\right]$, hydrogen peroxide $\left(\mathrm{H}_{2} \mathrm{O}_{2}\right)$, PVA (polyvinyl alcohol), glycerol, distilled water, ethylene gas, $0.1 \mathrm{~N} \mathrm{NaOH}, 0.01 \mathrm{~N}$ iod, filter paper, $1 \%$ starch indicator ,pp indicator, styrofoam, plastic wrap, LDPE plastic and avocado. While the equipment was erlenmeyer, measuring cup, goblet, $\mathrm{pH}$ meter, measuring flask, styrofoam, analytic balance, micropipette, electric stove, thermometer, dryer (vacuum oven, general oven, dual purpose oven), petri dish, cutter, colorimeter, penetrometer, refractometer, glass chamber, and gas chromatography (GC).

B. Methods

B.1. Indicator solutions
Color indicator solution was made from ammonium molybdate $\left[\left(\mathrm{NH}_{4}\right)_{6} \mathrm{Mo}_{7} \mathrm{O}_{24 \cdot 4} \mathrm{H}_{2} \mathrm{O}\right]$ and it was dissolved into hydrogen peroxide $\left(\mathrm{H}_{2} \mathrm{O}_{2}\right)$. Ammonium molybdate as much as $1 \mathrm{~g}$ was dissolved into $10 \mathrm{~mL}$ hydrogen peroxide then homogenized using magnetic stirrer until dissolved completely. Mixing of the two ingredients produced yellow solution. The solution was then stored in a cool room at $7^{\circ} \mathrm{C}$ for 3 days in order to stop air, resulting from the reaction, trapped in this solution.

\section{B.2. Label manufacturing}

The label was made by heating $100 \mathrm{~mL}$ of distilled water at a temperature range of $80-100^{\circ} \mathrm{C}$. After that, 3.5 grams of polyvinyl alcohol (PVA) was added into the water, then stirred it until PVA dissolved completely. The heating was stopped, then $2 \mathrm{~mL}$ glycerol was added as a plasticizer and 4 $\mathrm{mL}$ color indicator and then the solution was poured on a glass plate with $10 \mathrm{~cm} \times 15 \mathrm{~cm}$ size. The film then dried in 3 different of dryers, namely vacuum oven (D1), general oven (D2), and dualpurpose oven (D3) at $40^{\circ} \mathrm{C}$ for 18 hours. The best labels were labels with smooth surface appearance.

\section{B.3. Label packaging}

The film was released from the its mold and then cut in the size of $3 \mathrm{~cm} \times 3 \mathrm{~cm}$. The label was packaged with LDPE film to keep the label form being damaged or exposed freely from air (see Fig. 1). Based on research [10] stated that labels packed with LDPE plastic without a hole had better results than those that were not packaged or packaged with holes.

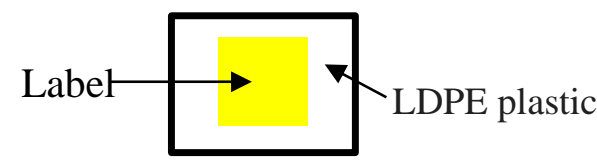

Fig. 1 Illustration of label packaged into LDPE plastic

\section{B.4. Label sensitivity test}

Label sensitivity test was aimed to determine the sensitivity of the label to ethylene gas at a certain concentration. The test was done by attaching the label on the inner surface of the 
chamber which was made from glass. Then ethylene gas was injected into the chamber using a gas tight syringe with concentrations of 100, 200, 300, 400, and $500 \mathrm{ppm}$. Label color changes were measured using a colorimeter four times a day with two repetitions for 10 days of storage. Change the color of the indicator label during storage was represented as a hue value, then plotted on the SigmaPlot version 14.0 application with the following equation:

$$
{ }^{\circ} \text { hue }_{\mathrm{t}}={ }^{\circ} \mathrm{hue}_{0}+\mathrm{a}\left(1-\mathrm{e}^{-\mathrm{bt}}\right)
$$

where ${ }^{\circ}$ hue $_{\mathrm{t}}$ is the value of ${ }^{\circ}$ hue at $\mathrm{t},{ }^{\circ} \mathrm{hue}_{0}$ is the value of ${ }^{\circ}$ hue at $t=0$, e is the exponent value of power is 2.718 , $\mathrm{t}$ was time, $\mathrm{a}$ and $\mathrm{b}$ is constants.

\section{B.5. Ethylene gas produced by avocado}

Measurement of ethylene gas produced by avocados was carried out using gas chromatography (GC). The procedure was done by storing the avocado in a tightly closed jar with hole in its lid for gas sampling. Gas sampling was carried out once a day for 10 days. The amount of ethylene gas produced was expressed in the ppm amount of ethylene gas per day.

\section{B.6 Label application for detecting fruit ripeness}

The purpose of this experiment was to determine the relationship of fruit maturity with label color changes. The test was done on avocado in pack and without pack. Avocado was placed on the styrofoam try and wrapped using PVC cling film as much as one piece for each package. The indicator label was attached inside the packaging. Meanwhile, for fruit that did not packed, labels was directly attached to the surface of the fruit. Samples were stored at room temperature $(28 \pm 1)^{\circ} \mathrm{C}$ for 10 days or until rotten. Observations were made on label color changes and fruit quality degradation which consisted of weight loss, total titrated acid and texture. Illustration of label applications can be seen in Fig. 2.

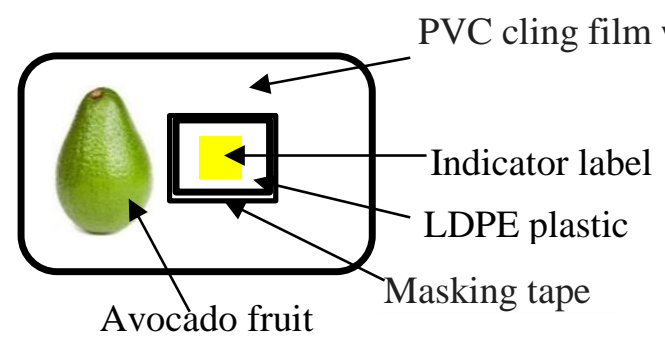

(a)

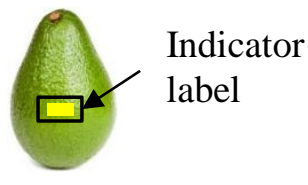

(b)

Fig. 2 Illustration of label applications for avocado (a) packaging and (b) without packaging

\section{RESULTS AND DISCUSSIONS}

\section{A. Effect of storing to indicator solution}

This preliminary research was carried out to develop proper label with smooth appearances. Experiments conducted [2] had produced a label with air trapped inside the film thus produce poor visual appearance of the label. Improvement was done by storing the color indicator solution (ammonium molybdate solution) in several temperatures to reduce the formation of $\mathrm{O}_{2}$. According to [11] that the bubbles formed in the solution has been caused by the presence of oxygen $\left(\mathrm{O}_{2}\right)$ resulting from the decomposition process of $\mathrm{H}_{2} \mathrm{O}_{2}$ which mixes with the catalyst. Ammonium molybdate catalyst will help the decomposed process of $\mathrm{H}_{2} \mathrm{O}_{2}$. This research results showed that the best appearance of the label was produced from film with the solution which kept in cool room at $7^{\circ} \mathrm{C}$ for 3 days before used it. The image of the film could be seen in Fig.3.

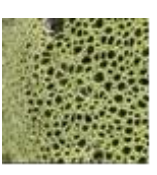

(a)

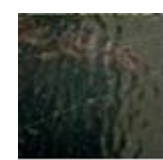

(b)

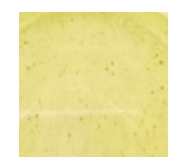

(c)
Fig. 3 Comparison of label appearance with a solution : (a) stored 0 hour [10], (b) stored 3 days at room temperature [10], and (c) stored 3 days at $7^{\circ}$ $\mathrm{C}$ (this experiment) 


\section{B. Effect of drying techniques for label manufacturing}

Film was dried in various type dryers i.e. vacuum oven (D1), general oven (D2), and dualpurpose ovens (D3). The drying process was carried at $40^{\circ} \mathrm{C}$ for 18 hours, and during the drying process, the dryer was closed tightly. Based on the observations in table 1, it can be seen that D1 produced label grey color and immediately change to blue when the film was released from the mold. Furthermore, the label looked moist due to high water content. It looked that the vacuum dryer was not enough heat to evaporate the water from the film solution. General oven (D2) produced smooth and shiny label with yellow color as it was expected. Label dried with general oven was the best method. D3 technique produced label with bubble and the color of label was grey thus the technique could not be used for color label making. According to [12], indicator labels can change color triggering by the presence of ethylene gas and $\mathrm{pH}$, temperature, and humidity thus drying technique could affect the appearance of the label.

Table 1. Label appearance based on drying technique

\begin{tabular}{c}
\hline Dryer $\quad$ Label appearance \\
D1 \\
D2 \\
D3 \\
\hline
\end{tabular}

\section{Effect label packing}

In this experiment, color indicator film was made by PVA and according to [13] PVA was dissolved easily in water, thus resulted on broken film, some of which were undergoing expansion and even torn and broken. PVA film has disadvantage of being unstable because of its hydrophilic nature which causes the film's texture to change when absorbing $\mathrm{H}_{2} \mathrm{O}$ [14]. An effort has been made by wrap the label with LDPE plastic. The results showed that the LDPE plastic could keep the color and appearance of the label during storage. LDPE plastic was chosen because it has mechanical properties which are strong, slightly translucent, and flexible. LDPE plastic at temperatures below $60^{\circ} \mathrm{C}$ is very resistant to chemical compounds and the protection against water vapor is good [15]. The label appearance was shown in Fig. 4.

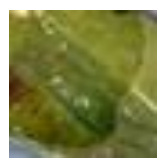

(a)

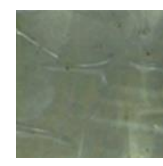

(b)

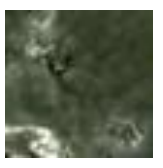

(c)
Fig. 4 Label appearance (a) without packaged [6], (b) packed LDPE plastic without holes, and (c) packed LDPE plastic with three holes [6]

\section{Ethylene Sensitivity Test}

In [2] study, at $250 \mathrm{ppm}$ of ethylene gas concentration and $500 \mathrm{ppm}$, color of indicator label had changed from yellow to green. Meanwhile, in the research of [16] using $30 \mathrm{PDDA} / \mathrm{SiO} 2$ film with a color indicator made of ammonium molybdate $\left[\left(\mathrm{NH}_{4}\right)_{6} \mathrm{Mo}_{7} \mathrm{O}_{24}{ }_{4} \mathrm{H}_{2} \mathrm{O}\right]$, palladium (II) sulfate $\left(\mathrm{PdSO}_{4}\right)$ and hydrogen peroxide $\left(\mathrm{H}_{2} \mathrm{O}_{2}\right)$, produced the film turned from white into a dark blue color when it exposed into ethylene gas. In this study, ethylene gas was applied at concentrations of 100 ppm, 200 ppm, 300 ppm, 400 ppm, and 500 ppm. The color of the label change visually from translucent to yellow and green. This color thus was observed and expressed quantitatively in hue (equation 1). Figure below show the changes in the value of ${ }^{\circ}$ hue and chroma at various concentrations of ethylene gas exposure. Based on the graph in figure 5, it was known that the higher the concentration of ethylene gas, the faster the indicator label change the color, expressed in high value of ${ }^{\circ}$ hue. Curve fitting by Sigma Plot using equation 1 show that all indicator labels with various ethylene gas concentration treatments were undergo steady or equilibrium, mean a zone where the label did not experience a further increase in the ${ }^{\circ}$ hue value. From the calculation, each treatment of ethylene gas concentration resulted on a different color change rate (Table 2). The higher the ethylene gas concentration, the color change rate tended to be higher and vice versa. 


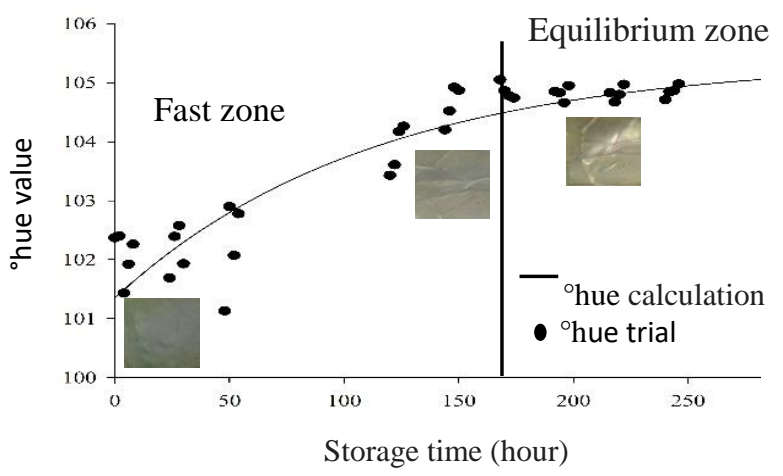

(a) Concentration of $100 \mathrm{ppm}$

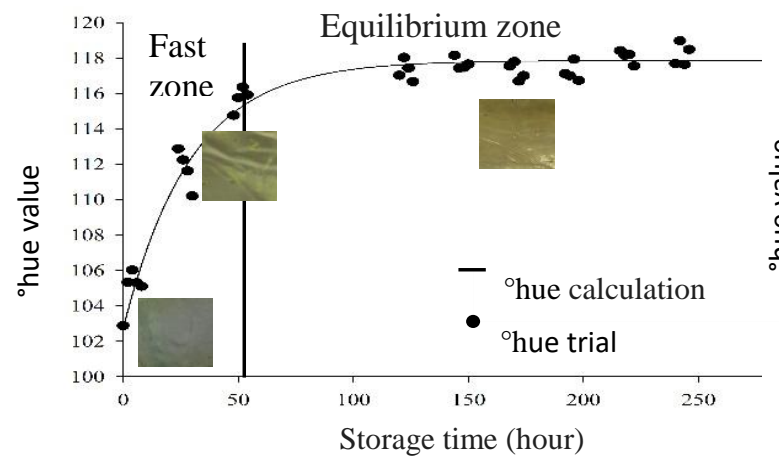

(c) Concentration of $300 \mathrm{ppm}$

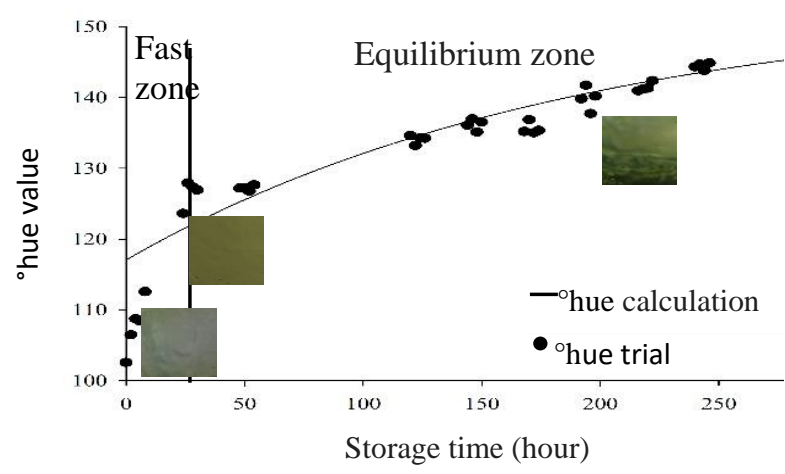

(e) Concentration of $500 \mathrm{ppm}$

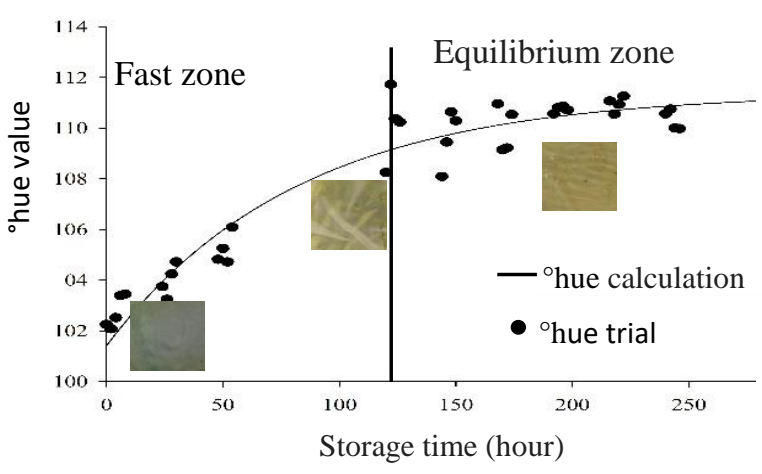

(b) Concentration of 200

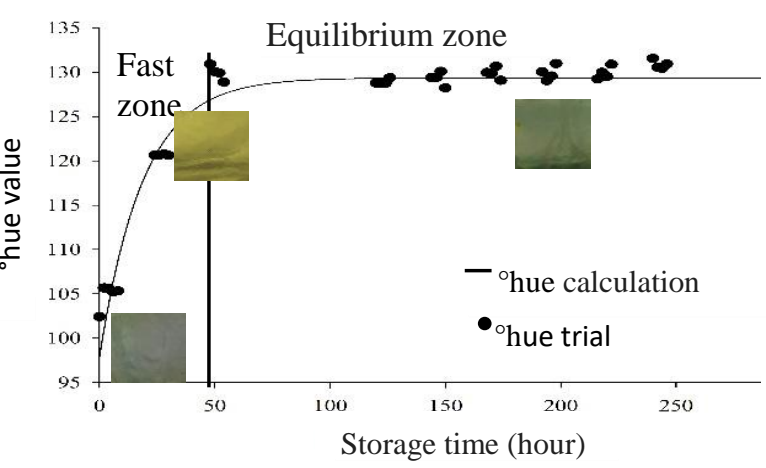

(d) Concentration of $400 \mathrm{ppm}$

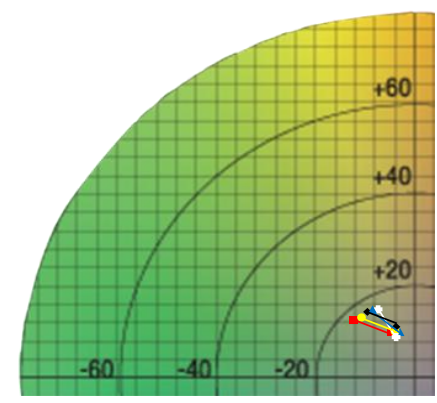

(f) Diagram of chroma and hue values

Fig. $5{ }^{\circ}$ hue values at various ethylene gas concentrations (a, b, c, d, and e), diagrams of changes in chroma and hue values at various ethylene gas concentrations (f) 
When the label was exposed in a chamber with ethylene concentration of $100 \mathrm{ppm}$, the label change the color quickly (fast zone) at 168 hours, furthermore at $200 \mathrm{ppm}$ concentration occurred at 122 hours, 300 ppm concentration was at 52 hours, $400 \mathrm{ppm}$ concentration was at 48 hours, and concentration $500 \mathrm{ppm}$ occurs at the 26 hour. Meanwhile, the chroma diagram also show the change in the indicator label color from transparent to yellow and green zone. The higher the ethylene gas exposed in the label, thus there was the more clearly visible the changing color of the label, namely from transparent yellow to greenish yellow. Each concentration of ethylene gas tested has produced a different rate of change in the value of hue and the comparison between the experimental data of ${ }^{\circ}$ hue and the calculated ${ }^{\circ}$ hue at $\mathrm{t}=0$ (initial) was not much different as shown in Table 2.

Table 2. Equation of the rate of change color at various ethylene gas concentrations

\begin{tabular}{cccc}
\hline $\begin{array}{c}\text { Ethylene gas } \\
\text { concentration } \\
(\mathrm{ppm})\end{array}$ & \multicolumn{1}{c}{ Equation } & Calculated $^{\circ}{ }^{\circ} \mathrm{hue}_{0}$ & Experiment $^{\circ}$ hue $_{0}$ \\
\hline 100 & ${ }^{\circ} \mathrm{hue}_{\mathrm{t}}={ }^{\circ} \mathrm{hue}_{0}+4.46\left(1-\mathrm{e}^{-0.347 \mathrm{t}}\right)$ & 101.44 & 102.37 \\
200 & ${ }^{\circ} \mathrm{hue}_{\mathrm{t}}={ }^{\circ} \mathrm{hue}_{0}+10.11\left(1-\mathrm{e}^{-0.012 \mathrm{t}}\right)$ & 101.46 & 102.25 \\
300 & ${ }^{\circ} \mathrm{hue}_{\mathrm{t}}={ }^{\circ} \mathrm{hue}_{0}+15.12\left(1-\mathrm{e}^{-0.036 \mathrm{t}}\right)$ & 102.56 & 102.88 \\
400 & ${ }^{\circ} \mathrm{hue}_{\mathrm{t}}={ }^{\circ} \mathrm{hue}_{0}+31.59\left(1-\mathrm{e}^{-0.053 \mathrm{t}}\right)$ & 97.87 & 102.42 \\
500 & ${ }^{\circ} \mathrm{hue}_{\mathrm{t}}={ }^{\circ} \mathrm{hue}_{0}+28.61\left(1-\mathrm{e}^{-0.011 \mathrm{t}}\right)$ & 114.61 & 102.57 \\
\hline
\end{tabular}

\section{E. Avocado's Ethylene Gas Production}

This ethylene gas production test aimed to find how much ethylene gas was produced by avocado during storage. Each fruit contains ethylene gas which varies depending on the type and age of the fruit. The older the fruitage was, the greater the content of ethylene gas will be, while the smaller the fruit's age, the content of ethylene gas is also small. The results can be seen in figure 6.It can be seen that the production of ethylene has increased and reached the peak of production on the $7^{\text {th }}$ day, namely $36.15 \pm 2 \mathrm{ppm}$ ethylene gas/day and gradually decreased to reach $10.34 \pm 2 \mathrm{ppm}$ ethylene gas on the $10^{\text {th }}$ day while the accumulation of ethylene avocado production for 10 days of storage reached $193.036 \mathrm{ppm}$ ethylene gas. This was consistent with [17] statement, which revealed that the fruit ripening process will show an increase in ethylene gas production until it reaches a certain peak, then this amount will decrease along the end of the fruit ripening process.

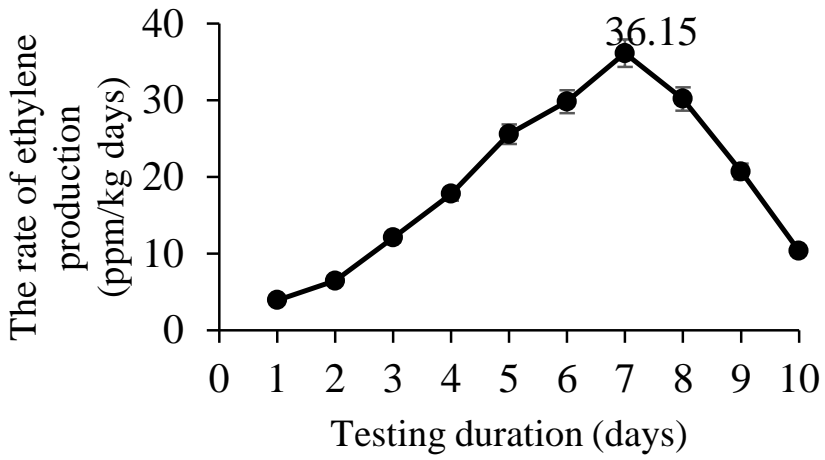

Fig. 6 Ethylene gas production for avocado

\section{E. Application of Indicator Labels on Fruits}

Fruit freshness detection labels were used to detect the amount of ethylene gas that accumulates in a fruit package. This label was used to provide information on the declining fruit quality during storage. The label was applied to avocado as shown in Fig. 7. The storage was carried out at room temperature $\left(28 \pm 1^{\circ} \mathrm{C}\right)$ for 10 days until the fruit was rotten. 


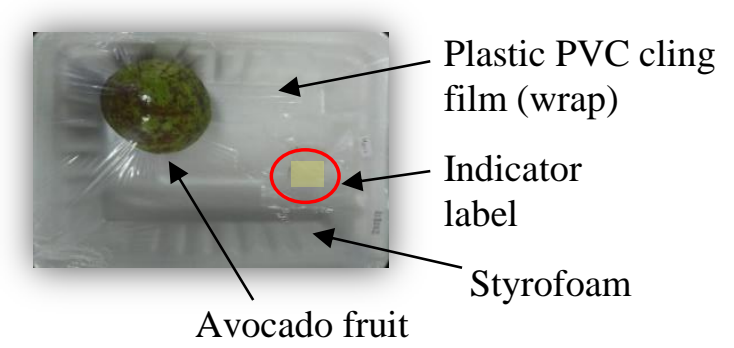

(a)

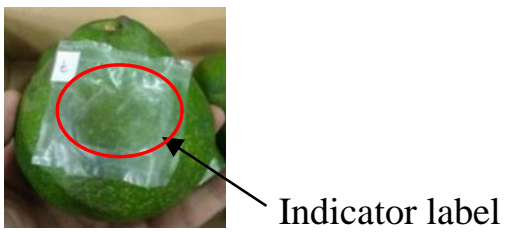

(b)

Fig. 7 Application of labels on avocado (a) attaching inside packaging and (b) attaching in the fruit surface

\section{F.1 Change color of the label}

Color is one indicator that can be easily accepted and understood by consumers. Based on Table 3 it can be seen that the color of the label changed with the fruit ripening process. Day 0 with ${ }^{\circ}$ hue 102.05 when the fruit was still unripe and the indicator label was yellow transparent. On the $6^{\text {th }}$ day with ${ }^{\circ}$ hue 103.93 when the fruit was fully ripe and the color of the indicator label which was originally yellow changes to a slightly greenish yellow. On the of $7^{\text {th }}$ to $10^{\text {th }}$, the color of the label did not change anymore until the rotten fruit. While the indicator label directly attached to the avocado surface, it was shown in table 4. In this experiment, the indicator label did not experience a significant color changes when it was viewed visually. This happens because of the ethylene gas produced by the avocado did not accumulate, but the gas released directly into the air, further the label of indicator could not absorb the gas and the color of indicator label was remain the same as original color.

Table 3. Visual appearance of indicator labels attached inside the packaged of avocado

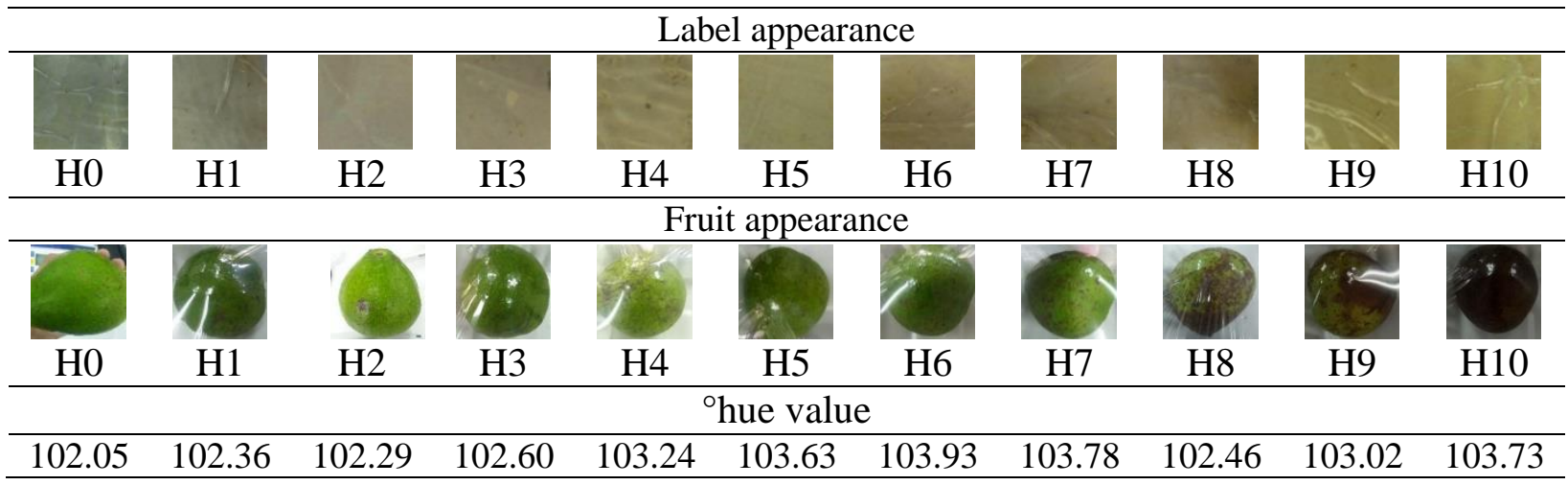

Table 4. Visual appearance of indicator labels attached in the surface of avocado

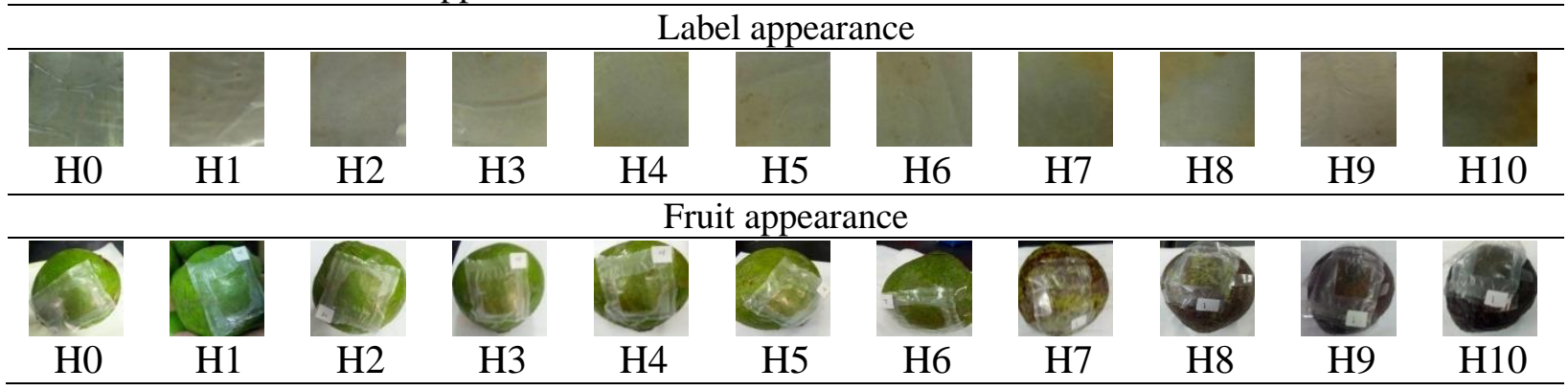


According to [16] the color change of the indicator label occurred from yellow to blue. But in the experiment, the color of the indicator label produced from yellow to greenish yellow. Based on research [18], that the chemical reaction between ethylene and molybdenum which has an effect on color changes has not been known in detail. Based on [19] study, ammonium molybdate mixed with acid of $\mathrm{HCl}$ and $\mathrm{H} 2 \mathrm{SO} 4$ has caused a reduction in Mo (VI) which produces $\left[\mathrm{Mo}_{2}(\mathrm{OH})_{2}\left(\mathrm{H}_{2} \mathrm{O}\right)_{6}\right]^{4+}$ which is green. This was supported by [20] study which received green molybdate due to the reduction of Mo (VI) when it was mixed with $\mathrm{HCl}$. But [21] added that the color change in the ammonium molybdate mixture could be affected by humidity, temperature, and sunlight.

The less significant color change of the indicator has occurred in this experiment. It seems that the number of avocado packed was not enough to produce a certain amount of ethylene gas which was significant to change the color of the label. It was shown that this experiment was only use 1piece of avocado per pack with an average weight of 350 grams. Within this number, it will produce ethylene gas with accumulation for 10 days of storage reaching 193,6 ppm ethylene gas /per pack. The permeability of the packaging material was also affecting the durability of the packaging in maintaining the content of ethylene gas inside the package. According to [22], plastic PVC cling film (wrap) had high permeability so that the air loss was high. Therefore, it is recommend that the packaged should contain enough number of avocado to produce significant amount of the ethylene gas.

\section{F.2 Fruit quality analysis \\ F.2.1. Fruit weight loss}

Weight loss is one indicator of decreasing fruit quality because it affects fruit conditions during storage. Based on the graph below, it can be seen that the percentage of loss avocado weight had increased with the length of storage. On first day, when the fruit was still raw, weight loss was obtained $(0.011 \pm 0.002) \%$, on the 6th day when the ripe fruit was obtained the weight loss was $(0.073 \pm 0.002) \%$ and continued to increase until the 10 th day when the fruit already rotten with weight loss $(0.123 \pm 0.002) \%$. In addition, the weight loss value was obtained linearly with a rate of 0.0121 which indicates that weight loss increased with time and showed a decrease in fruit quality. Weight loss in avocados occurs due to the transpiration and respiration processes which cause the fruit to lose water content [23]. According to [24] in the process of respiration, the carbon compounds contained in sugars will bind and react with oxygen and produce simpler compounds such as $\mathrm{H}_{2} \mathrm{O}$ and $\mathrm{CO}_{2}$ which are volatile so that the fruit loses its weight. In addition, the process of losing water to avocados can also be caused by the activity of microorganisms.

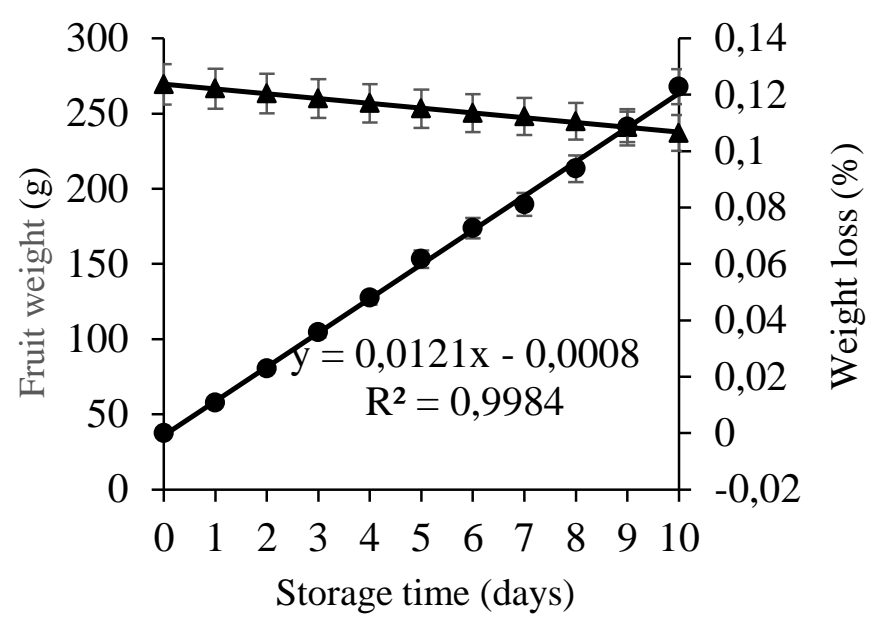

Fig. 8 Weight loss of avocado during storage

\section{F.2.2. Texture}

Fruit texture is one indicator of maturity and also a decrease in fruit quality. Texture value is indicated by the depth of the penetrometer needle which can enter the sample for 5 seconds. The greater the texture value obtained, the softer the fruit. The results of the texture test of avocado can be seen in figure 9 . Based on the graph, it can be seen that the value of fruit texture increases with storage time. On day 0 when the fruit was still raw, the fruit has an average hardness value of $(0.7 \pm 0.1)$ $\mathrm{mm} / 5 \mathrm{~s}$, when ripe on the $6^{\text {th }}$ day the average hardness value reached $(14.7 \pm 0.1) \mathrm{mm} / 5 \mathrm{~s}$, and when the fruit had rotten on the $10^{\text {th }}$ day the hardness value reaches an average $(21.2 \pm 0.1) \mathrm{mm} / 5$ $\mathrm{s}$, and the rate of increased in the value of avocado hardness was 2.2082. This showed that the fruit was getting softer with the ripening process. The increase of avocado texture value during the process of maturation or storage due to the degradation process of pectin by the enzyme activity of pectin methyl-esterase and polygalacturose, considering the avocado texture which is composed of polysaccharides, with the main components of cell walls are cellulose and pectin. As a result of this enzyme activity, the pectin which was originally insoluble in water became soluble in water. So that the cell wall will weaken and cohesion will decrease which binds cells to one another [20]. 


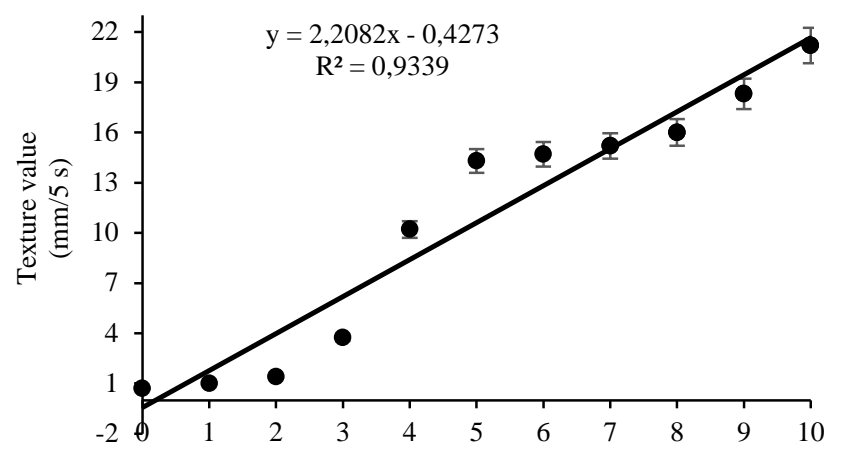

Storage time (days)

Fig. 9 Value of fruit hardness during storage

\section{G. Fruit Ripeness Indicator Label in Application}

Based on the research that has been done, the label can be used as a label of information on the level of ripeness of fruit for consumers. This was evidenced by the discoloration of smart labels during storage from fruit was still unripe, and then ripe and rotten. The similar research and results also was done by [25] and the stoichiometric calculation was explained by [26]. Illustration of smart labels in fruit packaging can be seen in Fig.10.

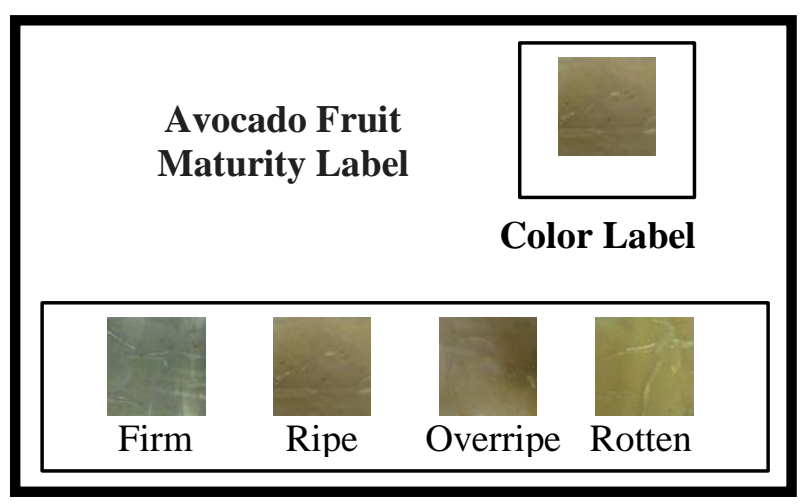

Fig. 10 Illustration of smart indicator labels for fruit ripeness

However, the color change of the label in the experiment was not clear, due to the concentration of ethylene gas in the packaging has not reached the minimum limit of sufficient concentration to change the color of the label. From the experimental data, the label sensitivity test found that the color of the indicator label will change color clearly at a concentration of ethylene gas at least $300 \mathrm{ppm}$. Meanwhile, based on the label application test in this research, the package containing a piece of avocado with an average weight of $350 \pm 3$ grams, showed that the avocado have been matured at day of $6^{\text {th }}$ and ethylene gas production experienced in peak at the $7^{\text {th }}$ day at about $36.15 \pm 2 \mathrm{ppm}$ ethylene gas/day, and the accumulation of ethylene gas of avocado for 10 days was $193.036 \mathrm{ppm}$. Therefore, in order to get a significant label color change each package should contains avocado with a weight of $1.5-2 \mathrm{~kg}$ with ethylene gas production between 300-400 ppm.

\section{CONCLUSIONS}

Based on the research conducted it can be concluded that the indicator label with smooth visual appearance can be made using a indicator solution after storage at temperature of $7^{\circ} \mathrm{C}$ for 3 days. Further, the film was dried using oven at $40^{\circ} \mathrm{C}$ for 18 hours. The color change of the label at various concentrations of ethylene gas was increasingly significant along the amount of the gas concentration. The production of ethylene avocado gas will continue to increase until it reached its maximum point and then it declined. A relationship between label color changes and fruit quality degradation was shown in this research and the response of the label was marked by yellow to greenish yellow. The minimum ethylene gas containing in the package of fruit should reach 300 ppm for 10 day for better performance of the indicator label. The reduction of avocado quality for 10 days was an increase in weight loss with a rate of increase of 0.0121 and an increase in the value of texture softness with a rate of increase of 2.2082 .

\section{REFERENCES}

[1] Brody AL, Eugene RS, Lauri RK. (2001). Active Packaging for Food Applications (United Stated:CRC Press) Cahp 7

[2] Endang W, Alberto BP, Chananpat R. (2017). Efficacy of Non-catalyzed Indicator as Smart Label Detecting Ripeness of Climacteric Fruits. Proc. of The $19^{\text {th }}$ Food Innovation Asia Conference 15-17 June 2017 Bangkok Thailand pp. 173-181.

[3] Paramita O. (2010). Effect of bruising to changing of respiration patterns, ethylene production, and mango tissue (Mangifera indica L.) var Gedong Gincu on a wide range of storage temperatures. Eng.Competention Journal 2(1) pp 29-37

[4] Indarto, Murinto. (2017). Maturity detection of bananas based on color features of banana skin image using HIS color space transformation method JUITA. 5(1) pp 15-21

[5] Yuwana. (1997). The acoustic method and the penetrometer computer controlled to measure the hardness of apples during storage. 
Bengkulu University Research Journal 10 pp 40-46

[6] Fenny A, Endang W, Ade I. (2018). Kinetic studies of potassium permanganate adsorption by activated carbon and its ability as ethylene oxidation material. IOP Conf. Series: Earth and Environmental Science. 141 (2018) 012003

[7] Warsik E, Citra DWP. (2012). Colored Label Indicator Using Natural And Synthetic Dye. $E$ Journal- Indonesia Agroindustry 1(2) p 82 - 87

[8] Warsiki E, Nofrida R, Yuliasih I. (2013). The Usage of erpa (Aerva sanguinolenta) leaf extract as color indicator label. Journal of Indonesia Agricultural Science 18(1) pp 16-19

[9] Warsiki E, Rahayuningsih M, Anggarani RR. (2016). Colored indicator media as Salmonella typhimurium detector. Agroindustrial Technology Journal 26 (3) pp 276-283

[10] Harmaji DD. (2017). Smart label for maturity detection of climatic fruit made from PVA (polyvinyl alcohol). [skripsi. Bogor (ID) Institut Pertanian Bogor

[11] Vetter TA, Philip C Jr. (2003). Kinetics of platinum-catalyzed decomposition of hydrogen peroxide. J. Chem Educ 80(7) p 788.

[12] Kim YH, Yang YJ, Kim JS, Choi DS, Park SH, Jin SY, Park JS. (2018). Non-destructive monitoring of apple ripeness using an aldehyde sensitive colorimetric sensor. Food Chem pp 149-158

[13] Mutia T, Rifaida E. (2012). The using of alginate/polyvinyl alcohol fiber resulting from electro spinning for primary wound band. Industry Research Journal 8(2) pp137-147

[14] Nofrida R, Warsiki E, Yuliasih I. (2013). The effect of storage temperature on the changing color of Erpa leave indicator smart label. Agroindustrial Journal 23(3) pp 232 - 241

[15] Massey LK. (2003). Permeability Properties of Plastics and Elastomers $2^{\text {nd }}$ Edition: A Guide to Packaging and Barrier Materials. Brent Beckley/William Andrew Publishing New York

[16] Kim JH, Shiratori S. (2006). Fabrication of color changeable film to detect ethylene gas. Japanese Journal of App Phy 45(5A) pp 4274-4278

[17] Nurjanah S. (2002). Study of respiration rate and ethylene production to determine the storage time of vegetables and fruits Bionatura J 4(3) pp148-156

[18] De-Liang L, Tsunashima R, Cronin L. (2010). Polyoxoxmetallates as building blocks for functional nanosystems (International Ed. in English). Angewandte Chemie 122 pp17801803
[19] Ullmann. (1996). Ullmann's Encyclopedia of Industrial Chemistry Weinheim (GER) Wiley$\mathrm{VCH}$

[20] Stark JG. (1969) The Oxidation States of Molybdenum. Liverpool (UK) Merchant Taylors' School

[21] Klein R, Riley N, DeCianne D, Srinavakul N. (2018). Non-invasive colorimetric ripeness indicator 15 Juni 2018 The University of Arizona Paten Amerika Serikat US 2006/0127543 A1

[22] Ifmalinda. (2017). Types of packaging data for tomato modified atmospheric storage. Agri Tech J 21(1) pp 1-7

[23] Wills RH, Lee TH, Graham D, Mc Gkasson, Hall WB. (1981). Postharvest: An Introduction to the Physiology and Handling Kensington Australia New South Wales University Press

[24] Syafutri MI, Pratama F, Saputra D. (2006). A physical and chemical properties of mango fruit (Mangifera indica L.) during storage with various packaging methods. Engineering and Food Industry 17(1) pp 1-11

[25] Putri VJ, Warsiki E, Syamsu K, Iskandar A. (2019). Application Nano Zeolite-Molybdate For Avocado Ripeness Indicator. IOP Conference Series: Earth and Environmental Science, $\quad 347, \quad 12063$. https://doi.org/10.1088/17551315/347/1/012063

[26] Warsiki E, Iskandar A, Ghiyas HM. (2020). Theoretical calculation and experimental validation of ammonium molybdate concentration for fruit ripeness indicator label. IOP Conference Series: Earth and Environmental Science, 472, 12017. https://doi.org/10.1088/17551315/472/1/012017 